\title{
SELF-DEFENCE AND CONSENT: THE USE OF COMMON LAW DEVELOPMENTS IN CANADIAN CRIMINAL CODE ANALYSIS
}

\section{ANNE STALKER}

The author examines the interaction between the Criminal Code and the common law in relation to two areas of law recently handled by both the Alberta Court of Appeal and the Supreme Court of Canada - excessive use of force in self-defence and consent to assault causing bodily harm. She argues that a proper approach to the question of when it is legitimate to allow common law additions to the Code is first to look to the Code to see if there is room for the principle being discussed (without giving the Code, a general statute, too restrictive a reading) and then to do a comprehensive common law analysis of the principle to see how strong and defensible it is, and whether it can overcome whatever statutory resistance exists. It is only if a thorough analysis is done of both the Code and the common law that the criminal law will be able to develop most effectively. It is the position of the author that each of the Supreme Court and the Alberta Court of Appeal has done part of this analysis well but neither has recognized the need to conduct a complete investigation.
L'auteure examine l'interaction entre le Code Criminel et la common law en ce qui touche deux questions de droit récemment abordées par la cour d'appel de l'Alberta et la Cour suprême du Canada - le recours a la force excessive en cas de légitime défense, et le consentement aux voies de fait causant des lésions corporelles. Elle soutient que la façon appropriée de s'interroger sur la légitimité de tout ajout de la common law au Code, consiste à vérifier en premier lieu si le Code permet que le principe soit discuté (sans assujettir le Code, qui est général, à une lecture trop restrictive) et de soumettre ensuite le principe à une analyse approfondie de la common law afin de vérifier s'il est solide et défendable, et s'il est en mesure de surmonter toute résistance statutaire éventuelle. C'est seulement au terme d'une analyse approfondie du Code et de la common law que le droit criminel pourra évoluer le plus efficacement. L'auteure est d'avis que la Cour suprême et la cour d'appel de l'Alberta ont toutes deux effectué des analyses partielles mais que ni l'une ni l'autre n'ont éprouvé le besoin de procéder à une ćtude complète.

\section{TABLE OF CONTENTS}

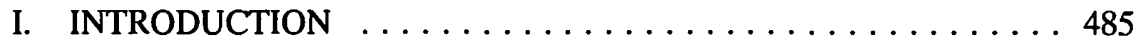

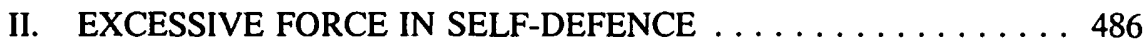

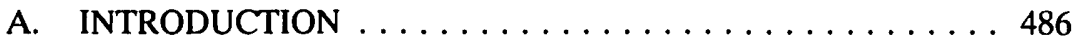

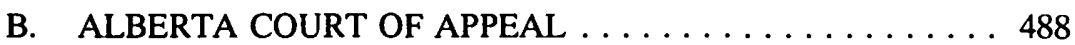

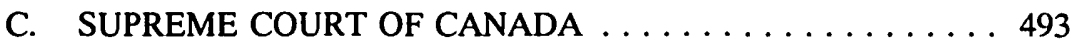

D. COMPARISON OF THE TWO APPROACHES

TO EXCESSIVE FORCE . . . . . . . . . . . . . . . . . 499

III. THE RELEVANCE OF VICTIM'S CONSENT IN

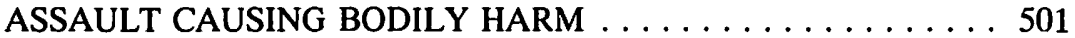

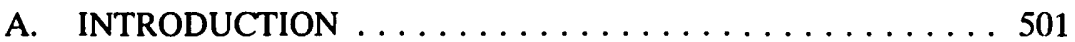

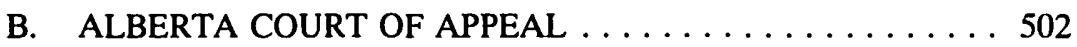

C. THE SUPREME COURT OF CANADA .......... 506

D. COMPARISON OF THE TWO APPROACHES TO

CONSENT IN ASSAULT CAUSING BODILY HARM $\ldots .508$

IV. CONCLUSION $\ldots \ldots \ldots \ldots \ldots \ldots \ldots \ldots \ldots \ldots \ldots \ldots$ 


\section{INTRODUCTION}

The existence of a Criminal Code ${ }^{1}$ in Canada creates a serious issue about the exact legal nature of criminal law. The basic policies and principles of criminal law were developed at common law. In 1892, the Parliament of Canada adopted a Criminal Code ${ }^{2}$ based in large part on the criminal law of England - a criminal law which developed at common law. Since then, Canadian criminal law has developed in the shadow of an overarching, but certainly not all-inclusive, statute. Canadian criminal law has had to forge its own legal process because of the curious interaction between the Code and common law. It is not yet clear exactly what that process is, as an examination of recent criminal law developments through the Alberta Court of Appeal and the Supreme Court of Canada will show. However, through an analysis of the different approaches used by these courts, including their strengths and weaknesses, it is possible to begin to mould a set of principles by which a court's approach can be judged.

I will use two major issues to examine this topic. Both are recent issues in which the Alberta Court of Appeal has had to deal with a line of cases and, through its work with that line of cases, has devised a solution to the issue. In both areas, the Alberta Court of Appeal's approach was rejected by the Supreme Court of Canada in cases that followed quickly after the Alberta decisions (i.e. within the same societal environment.) One issue, that of the availability of a qualified defence reducing murder to manslaughter when the accused has killed in self-defence but has used excessive force, arose over a decade ago. The other, the question of whether force causing bodily harm is an offence when the victim has consented to the force used, has only very recently worked its way through the Alberta Court of Appeal and the Supreme Court of Canada. The two examples are thus taken from courts a decade apart, and the effect of that time difference will be part of the analysis.

Examining in detail the judgments of any court is, of course, perilous. A court is not a unified body and decisions, even when written on behalf of the whole court, are written by one person only. Thus, it can be misleading to interpret a single idea or phrase as representative of the views of the court itself. However, my aim here is not to be descriptive, but is to try to cajole a distinctive and useful approach to criminal law jurisprudence from the material available. Therefore, even if I am not always accurate (as I could not possibly be) in assessing what the actual views of the courts themselves are, the possibilities I explore are still useful options in the hunt for the most appropriate model for Criminal Code interpretation. Other writers, with perhaps different views of what was happening in these (or other) cases, can then carry on the exploration. references to Criminal Code provisions will be to this revision. When there is a reference to a previous revision of the Code in a quotation or discussion, it will be followed by the equivalent section number in the above revision in square brackets. 


\section{EXCESSIVE FORCE IN SELF-DEFENCE}

\section{A. INTRODUCTION}

The first substantive area that provides some insights into the approaches the two courts have taken to the fit between the Criminal Code and the common law is the use of excessive force in self-defence or in some similar justification defence such as preventing the commission of a crime. The issue arises in the following way. On the facts as found, the accused would have been justified in using some force either to prevent the commission of an offence or in self-defence under one of the provisions available in the Code. In the circumstances, however, there were no reasonable grounds for the accused to believe that it was necessary to use force that would cause death or serious ("grievous") bodily harm to prevent some harm to him or herself. Nevertheless, the accused believed such force was necessary and ultimately killed the victim. It is clear that the accused does not have a full defence for the killing because the amount of force was not reasonably necessary; the argument is rather that, even if the accused did intend to kill, he or she should be convicted of manslaughter instead of murder.

The main provisions of the Code that justify the use of force and are therefore relevant to this issue are the following:

s. 27 Every one is justified in using as much force as is reasonably necessary

(a) to prevent the commission of an offence

(i) for which, if it were committed, the person who committed it might be arrested without warrant, and

(ii) that would be likely to cause immediate and serious injury to the person or property of anyone; or

(b) to prevent anything being done that, on reasonable grounds, he believes would, if it were done, be an offence mentioned in paragraph (a).

s. 34(1) Every one who is unlawfully assaulted without having provoked the assault is justified in repelling force by force if the force he uses is not intended to cause death or grievous bodily harm and is no more than is necessary to enable him to defend himself.

(2) Every one who is unlawfully assaulted and who causes death or grievous bodily harm in repelling the assault is justified if

(a) he causes it under reasonable apprehension of death or grievous bodily harm from the violence with which the assault was originally made or with which the assailant pursues his purposes; and

(b) he believes, on reasonable grounds, that he cannot otherwise preserve himself from death or grievous bodily harm.

s. 35 Every one who has without justification assaulted another but did not commence the assault with intent to cause death or grievous bodily harm, or has without justification provoked an assault on himself by another, may justify the use of force subsequent to the assault if

(a) he uses the force 
(i) under reasonable apprehension of death or grievous bodily harm from the violence of the person whom he has assaulted or provoked, and

(ii) in the belief, on reasonable grounds, that it is necessary in order to preserve himself from death or grievous bodily harm;

(b) he did not, at any lime before the necessity of preserving himself from death or grievous bodily harm arose, endeavour to cause death or grievous bodily harm; and

(c) he declined further conflict and quitted or retreated from it as far as it was feasible to do so before the necessity of preserving himself from death or grievous bodily harm arose.

s. 36 Provocation includes, for the purposes of sections 34 and 35, provocation by blows, words or gestures.

s. 37(1) Every one is justified in using force to defend himself or any one under his protection from assault, if he uses no more force than is necessary to prevent the assault or the repetition of it.

(2) Nothing in this section shall be deemed to justify the wilful infliction of any hurt or mischief that is excessive, having regard to the nature of the assault that the force used was intended to prevent.

There is a statutory precedent for reducing murder to manslaughter, even though the requirements for murder are otherwise met. It is the defence of provocation:

s. 232.(1) Culpable homicide that otherwise would be murder may be reduced to manslaughter if the person who committed it did so in the heat of passion caused by sudden provocation.

(2) A wrongful act or insult that is of such a nature as to be sufficient to deprive an ordinary person of the power of self-control is provocation for the purposes of this section if the accused acted on it on the sudden and before there was time for his passion to cool.

(3) For the purposes of this section, the questions

(a) whether a particular wrongful act or insult amounted to provocation, and

(b) whether the accused was deprived of the power of self-control by the provocation that he alleges he received,

are questions of fact, but no one shall be deemed to have given provocation to another by doing anything that he had a legal right to do, or by doing anything that the accused incited him to do in order to provide the accused with an excuse for causing death or bodily harm to any human being.

(4) Culpable homicide that otherwise would be murder is not necessarily manslaughter by reason only that it was committed by a person who was being arrested illegally, but the fact that the illegality of the arrest was known to the accused may be evidence of provocation for the purposes of this section. 
There is, however, no similar provision in the Code reducing murder to manslaughter when the accused has used excessive force in self-defence or preventing the commission of a crime. The only potentially relevant Code provisions, other than those reproduced above are:

s. 8(3) Every rule and principle of the common law that renders any circumstances a justification or excuse for an act or defence to a charge continues in force and applies in respect of proceedings for an offence under this Act or any other Act of Parliament except in so far as they are altered by or are inconsistent with this Act or any other Act of Parliament.

s. 26

Every one who is authorized by law to use force is criminally responsible for any excess thereof according to the nature and quality of the act that constitutes the excess.

This then is the factual and statutory framework for the issue of use of excessive force in self-defence.

\section{B. ALBERTA COURT OF APPEAL}

The Alberta Court of Appeal has addressed this issue on three occasions within the last fifteen years, in $R$. v. Fraser, ${ }^{3} R$. v. Gee $e^{4}$ and $R$. v. Faid. ${ }^{5}$ In all three cases, they recognized the validity of reducing a murder charge to manslaughter when the accused had been acting in self-defence but had used excessive force.

\section{R. v. Deegan}

The idea was actually first introduced in Alberta in a concurring opinion by Prowse J.A., writing for himself only, in $R$. v. Deegan. ${ }^{6}$ In that case, the accused had been in an argument with the deceased and had hit the deceased. After the accused returned to his own apartment, just down the hall, the deceased followed him there and tried to break the door down. A fight ensued during which the deceased kicked the accused in the face twice, and the accused stabbed the deceased and another person who was trying to stop the fight. The deceased later died of his wounds and the accused was convicted of murder. The majority in the Court of Appeal found that the trial judge's charge to the jury on selfdefence, provocation and defence of property was not adequate.

Prowse J.A. agreed with the majority on these points but, in addition, thought that the jury should have been charged on the possibility of a verdict of manslaughter if their sole reason for rejecting self-defence was that the accused had used more force than a reasonable person would have considered necessary. Prowse J.A. recognized that the basic self-defence section, s. 34, did not cover this situation. He acknowledged that, if the accused used more force than considered necessary by the reasonable person, even while personally believing the force was not more than was necessary, self-defence per se was 
not available. However, in these circumstances, Prowse J.A. characterized the accused's state of mind as "the intent to kill in self-defence" and found it not to be the type of "intent to kill" contemplated by s. 212(a) (now s. 229(a)). Section 229(a) reads as follows:

s. 229 Culpable homicide is murder

(a) where the person who causes the death of a human being

(i) means to cause his death, or

(ii) means to cause him bodily harm that he knows is likely to cause his death, and is reckless whether death ensues or not; ...

He considered the analyses in $R$. v. Paquette, ${ }^{7}$ R. v. Stean $e^{8}$ and $R$. v. George, ${ }^{9}$ each of which refined the concept of intention. He then found that the intent to kill formed out of a genuine fear for one's own life, albeit that such fear was unreasonable, did not amount to the specific intent required for murder because the actions involved were the purely physical products of fear and therefore insufficiently thought out to show specific intent.

\section{R. v. Fraser and R. v. Gee}

The Alberta Court of Appeal had the opportunity to revisit this point a year later in two cases released on the same day, $R$. v. Fraser ${ }^{10}$ and $R$. v. Gee. ${ }^{11}$

The central judgment of the Alberta Court of Appeal on excessive force was the majority judgment in Fraser, written by Moir J.A. with Lieberman J.A. concurring. Fraser was a taxi-driver who picked up the deceased and then spent the evening with him at a casino. He went to the deceased's apartment where they continued drinking and taking drugs. The deceased made two homosexual advances to the accused and the accused beat the deceased with the deceased's cane, ultimately causing his death. The trial judge found that the accused perceived the homosexual advances as a serious threat but that he also knew he was using excessive force. He was convicted of manslaughter on the basis that he used excessive force in self-defence.

Moir J.A. adopted the position taken by the High Court of Australia in $R$. v. Howe $e^{12}$ and Viro v. The Queen ${ }^{13}$ that, where an accused is justified in using some force for selfdefence and honestly believes the amount of force he or she is using is appropriate, the

(1976), 30 C.C.C. (2d) 417 (S.C.C.), where it was held that an accused who drove a car for robbers under duress did not hold a common intention with them.

[1947] 1 All E.R. 813 (C.A.), where it was held that an accused who did newsreading and acting jobs for the Nazis during World War II in order to avoid injury to himself and his family did not have the "intent to assist the enemy."

(1960), 128 C.C.C. 289 (S.C.C.), where the court distinguished the physical products of momentary passion (general intent) from the deliberate steps necessary to achieve a goal (specific intent).

Supra note 3.

Supra note 4.

(1958), 100 C.L.R. 448 (Aust. H.C.) [hereinafter Howe].

(1978), 141 C.L.R. 88 (Aust. H.C.) [hereinafter Viro]. 
offence committed is manslaughter and not murder if the court finds the force used to be excessive as viewed by the reasonable person and therefore not justified as self-defence. Moir J.A. quoted extensively from Howe and Viro, choosing quotes which indicate that the rationale behind his approach is that, even though the accused may have intended to cause death, the circumstances show that there was no malice aforethought (the mental element required for murder in England and those states of Australia in which these cases were decided.)

In Canada, malice aforethought is not an element of the offence of murder; as we have seen, murder is defined in s. 229(a) of the Code by direct reference to intent. Prowse J.A. in Deegan ${ }^{14}$ appeared to read into the meaning of intent the qualitative elements the Australian Court had found in malice aforethought (i.e. the offence required not only intent to cause death but intent to cause death for no good reason). Moir J.A., on the other hand, preferred to leave intent as a simple descriptive element but use the underlying principle of the Australian approach to justify a defence that would alleviate the unresponsiveness of the Canadian definition of murder. He described his policy in the following way: "The effect of the defence is not to negative the intention to kill or to cause injury but to hold that an intent to kill or injure, when force is permissible, is less morally culpable than the intent to kill or injure recklessly under other circumstances. ${ }^{.15}$ He then went on to say that such a qualified defence could and should be brought into Canadian Criminal law via the route of s. 7(3) (now s. 8(3)) of the Code. One aspect that is unclear is whether he offered this defence as a traditional, previously-existing common law defence or whether he was proposing it as a new defence. ${ }^{16}$ In any event, Moir J.A. made it obvious that he considered the defence useful, reasonably well-substantiated in both precedent and principle, and consistent with the application of the Code. Finally, he established a test for the defence and the charge to the jury that should be used in Canada:

1. certain serious circumstances must exist which led the accused to reasonably believe a situation involving danger existed;

2. the accused used unreasonable or excessive force; and

3. the accused was acting honestly when he used excessive force in that he mistakenly believed that the degree of force he was using was reasonable. ${ }^{17}$

Supra note 6.

Supra note 3 at 522 .

It is unlikely that the question of whether the defence was a previously existing one or a new one would make any difference to its acceptability under s. 8(3). Two strong minority decisions in the Supreme Court of Canada have expressed the opinion that the nature of the common law is an evolving one and that therefore it cannot be viewed as frozen at any particular time. (Laskin, C.J.C. in R. v. Kirzner, (1978) 38 C.C.C. (2d) 131 (S.C.C.) at 138; Estey, J. in Amato v. The Queen, (1982) 69 C.C.C. (2d) 31 (S.C.C.) at 59-60 with Laskin C.J.C., McIntyre and Lamer J.J. concurring.) I have not been able to find any contrary opinions on this point from the Supreme Court of Canada.

Supra note 3 at 523, adopting the test from Viro, supra note 13. 
The charge to the jury takes this test and translates it into a series of steps that the jury must go through when deciding whether the defence will apply. Because of the difficulties of incorporating the burden of proof requirements, the charge to the jury is long and complicated, as seen from this quote from Moir J.A.'s judgment in Fraser:

Where the defence of self-defence is put forward the trial Judge must direct the jury. That direction should be as set forth by Mason J. in Viro v. The Queen at pp. 302-3:

"Accordingly, where threat of death or grievous bodily harm to the accused is in question and the issue of self-defence arises the task of the jury must be stated as follows:

(1)(a) It is for the jury first to consider whether when the accused killed the deceased the accused reasonably believed that an unlawful attack which threatened him with death or serious bodily harm was being or was about to be made upon him.

(b) By the expression 'reasonably believed' is meant, not what a reasonable man would have believed, but what the accused himself might reasonably believe in all the circumstances in which he found himself.

(2) If the jury is satisfied beyond reasonable doubt that there was no reasonable belief by the accused of such an attack no question of self-defence arises.

(3) If the jury is not satisfied beyond reasonable doubt that there was no such reasonable belief by the accused, it must then consider whether the force in fact used by the accused was reasonably proportionate to the danger which he believed he faced.

(4) If the jury is not satisfied beyond reasonable doubt that more force was used than was reasonably proportionate it should acquit.

(5) If the jury is satisfied beyond reasonable doubt that more force was used, then its verdict should be either manslaughter or murder, that depending upon the answer to the final question for the jury - did the accused believe that the force which he used was reasonably proportionate to the danger which he believed he faced.

(6) If the jury is satisfied beyond reasonable doubt that the accused did not have such a belief the verdict will be murder. If it is not satisfied beyond reasonable doubt that the accused did not have that belief the verdict will be manslaughter."18

While Moir J.A. found that excessive force in self-defence was not available to the accused in this case because the trial judge had found that he knew the force was excessive, he held that there had also been a misdirection on provocation and the case should be sent back for a new trial on provocation. McDermid J.A. dissented. He agreed that excessive force in self-defence was not available based on his own analysis in Gee, 
but also found that provocation was not a possible verdict and therefore would have convicted of murder.

In $G e e,{ }^{19}$ the other decision delivered the same day, the accused and two friends were visiting the deceased for some "kinky" activities, which may have included robbing him. The deceased attacked one of the friends in circumstances that were unclear. In coming to their friend's aid, the accused and the other friend, a co-accused, beat the deceased to death. Both were convicted of murder.

In reviewing the arguments available to Gee and his co-accused, Prowse J.A. repeated and expanded on his analysis in Deegan ${ }^{20} \mathrm{He}$ acknowledged its debt to provocation and the common basis of loss of control. However, in Gee the accused's argument was based on prevention of a crime (s. 27) rather than self-defence, and so the Code analysis was more complicated. As Prowse J.A. pointed out, because use of force to prevent a crime is not as fully covered in the Code as self-defence, the proportionality requirements that are expressly part of s. 34 must be read into s. 27 . For instance, a literal reading of s. 27 would allow a person to kill someone who was only causing serious damage to property; however, the common law in the area has required the same limitations as exist in s. 34(2) to be read in, so that the injury to be avoided must be proportional to the injury caused, and therefore an accused could be justified in causing death only when the crime being prevented involved death or grievous bodily harm. Similarly, the law applying to an accused who used excessive force while believing it not to be excessive would be the same in prevention of crime situations as in self-defence; i.e. an accused who believed it was necessary to kill to prevent a serious crime involving injury to another would not have formed a properly reasoned intent to kill and, even if the force was in fact excessive, would be guilty of manslaughter only.

Moir J.A. agreed with Prowse J.A. in the result, but not in the reasons. Specifically, he rejected the idea that the intent to kill was affected by the miscalculation of excessive force and instead embraced the principle that the intent existed but was excused in these kinds of mitigating circumstances. Moir J.A. referred to his reasons in Fraser (discussed above) and stated that the same analysis should apply to all justifiable uses of force, including force used to prevent a crime.

McDermid J.A., in a short opinion, concluded that "...the moral culpability of a person who in order to prevent the commission of a violent crime uses more force than is necessary, but not more force than he believes necessary, is not such as to make him guilty of murder but only of manslaughter."121 $\mathrm{He}$ felt that there was enough Canadian authority and enough difference between Canadian and English criminal law experience to enable him to take this approach despite the fact that the English courts had rejected 
it. $^{22}$ It is unclear whether he viewed his approach as different from Moir J.A.'s. While he appeared to approve of and rely on Viro, ${ }^{23}$ a case which also grounded Moir J.A.'s analysis in Fraser, he nowhere indicated that his analysis was the same as that of Moir J.A. In any event, it is certainly clear that he did not accept Prowse J.A.'s analysis that the murder is reduced to manslaughter because the specific intent to kill was not present.

\section{R. v. Faid}

The final chapter of the Alberta Court of Appeal volume on the qualified defence of excessive force in self-defence was written by Harradence J.A. in R. v. Faid. ${ }^{24}$ There, writing for the Court, he pointed out that some version of the qualified defence had been accepted by all members of the Courts hearing Fraser and Gee. He quoted the conclusions from the judgments of Moir J.A. in both cases. Then, after setting out the self-defence section, s. 34(1) and (2), he stated that the idea of excessive force was within the 'purview' of s. $34(2)^{25}$ and that the trial judge in Faid had an obligation to charge the jury on manslaughter based on excessive use of force in self-defence. It was now clear that the qualified defence had been fully accepted by Alberta's highest court.

\section{SUPREME COURT OF CANADA}

\section{R. v. Brisson}

Just over a year later, the Supreme Court of Canada began the operation of dismantling the defence. While a majority of the Court ultimately applied the same reasoning in its subsequent decisions in the appeals of both $R$. v. Gee $e^{26}$ and $R$. v. Faid, ${ }^{27}$ it was in $R$. v. Brisson, ${ }^{28}$ an appeal from the Quebec Court of Appeal, that the basic analysis was first developed. In Brisson, five judges held that there was insufficient evidence to justify putting the issue of self-defence before the jury, and that therefore the question of manslaughter due to excessive self-defence did not arise. Dickson, J., however, in a judgment concurred in by the other three remaining judges, directly addressed the question of whether the use of excessive but honest force in self-defence could reduce murder to manslaughter and held that it could not.

E.g. in Palmer v. The Queen, [1971] 1 All E.R. 1077 (P.C.) (Jamaica); R. v. McInnes, [1971] 3 All E.R. 295 (C.A.), both dealing with the excessive use of force in self-defence, and Reference under s. 48A of the Criminal Appeal (Northern Ireland) Act 1968 (No. I of 1975), [1976] 2 All E.R. 937 (H.L.), dealing with the excessive use of force in prevention of a crime. It should be noted that the first two decisions dealt with the common law defence of self-defence while the last dealt with the defence of prevention of crime as set out in s. 3 of the Criminal Law (Northern Ireland) Act 1967.

lbid. at 35 .

(1982), 68 C.C.C. (2d) 516 (S.C.C.).

(1983), 2 C.C.C. (3d) 513 (S.C.C.).

(1982), 69 C.C.C. (2d) 97 (S.C.C.) [hereinafter Brisson]. 
Dickson J. attacked the defence from several vantage points. He started from the position that the basic difference in principle between murder and manslaughter was intent and that, in Canada, the one exception was the specifically codified defence of provocation (s. 232). Moreover, there was quite a complex series of sections dealing with justified uses of force to prevent crime and to protect oneself, one's dependents and one's property and allowing a complete defence to all kinds of culpable homicide. It was against this Canadian framework that he constructed his analysis.

First, he acknowledged that the Alberta Court of Appeal had been the Canadian court that had been most hospitable to the doctrine. However, the fact that Prowse J.A. and Moir J.A. (and even potentially McDermid J.A.) had disagreed on its basis undermined the strength and persuasiveness of Alberta's approach. Relying on the framework established earlier, Dickson J. pointed out that Prowse J.A.'s reliance on lack of intent left it unclear what he meant by intent and that Moir J.A.'s reliance on the reduced moral culpability of such an intentional killing, similar to provocation, ignored the fact that Parliament had specifically recognized provocation but not qualified self-defence. Furthermore, the charge to the jury in Viro, which Moir and Lieberman J.J.A. had adopted in Fraser, ${ }^{29}$ was too complicated.

There were thus three problems which Dickson J. identified and which he went on to support more fully. There was lack of principle, lack of fit with the Code and the danger of confusing the jury with complicated charges. After examining the situation across Canada, he stated:

\footnotetext{
A review of the Canadian authorities shows a singular lack of uniformity in result and in reasoning. It is difficult to say that the cases follow any pattern, or the law of any country, or that, to date, any clear statement of principle has emerged. ${ }^{30}$
}

This was overstatement, to say the least. Although many of the decisions did not engage in a discussion of principle (the Alberta Court of Appeal being one of the few Courts that struggled with the reasons for allowing a qualified defence of excessive self-defence), only one province (Manitoba) ${ }^{31}$ had rejected the idea. Moreover, even Manitoba could not conclusively be said to have rejected this concept of the qualified defence; the version they discussed appeared to be a different qualified self-defence, where excessive force on its own, without an honest belief in the need for that force, would automatically reduce murder to manslaughter. It is fair to say that the great majority of Canadian Courts of Appeal (i.e. British Columbia, ${ }^{32}$ Alberta, ${ }^{33}$ Saskatchewan, ${ }^{34}$ Ontario ${ }^{35}$ and Quebec ${ }^{36}$ )

\author{
See supra note 3 at 524 . \\ Supra note 28 at 112. \\ R. v. Appleby, [1979] 1 W.W.R. 664 (Man. C.A.). \\ R. v. Barilla (1944), 82 C.C.C. 228 (B.C.C.A.); R. v. Ouellete (1950), 98 C.C.C. 153 (B.C.C.A.). \\ Recent cases are more equivocal. In $R$. v. Basarabas and Spek (1981), 62 C.C.C. (2d) 13 \\ (B.C.C.A.), the Court would allow the doctrine to apply to only some forms of self-defence and \\ in $R$. v. Stanley (1977), 36 C.C.C. (2d) 216 at 232 (B.C.C.A.), a case in which there was \\ apparently no intent to cause death and the specific issue therefore did not arise, the Court made \\ a somewhat ambiguous reference to the availability of manslaughter only if there were no intent \\ as required for murder. A more proper construction is, however, that the Court did not consider
}


that had considered the question of the position of a person who was justified in using force in self-defence and who unknowingly went beyond the force that was necessary and thereby caused death had ultimately approved of the idea of convicting such an accused of manslaughter only.

Moreover, the concern over the lack of clear and uniform principle is exaggerated. It is true that the test and principle accepted by the Alberta Court of Appeal can be subjected to criticism. In particular, the test has two separate requirements - that the accused be in a position where some force is actually justified and that the accused overreact and cause death due to an unreasonable but honest belief that to cause serious injury or death is necessary. These two requirements are based on two separate principles. The requirement that some force be justified indicates a concern with fairness based on proportionality; the difference between the person acting legally and the accused is not as extreme in the case of excess only as in the case where no force would be justified and the behaviour is therefore totally unlawful from the beginning. The second requirement, that the accused honestly believe that causing serious injury or death is necessary, indicates a concern with fairness based on our notions of responsibility; it is akin to the normal requirement of mens rea. It recognizes that a person acting under mistaken belief is making choices based on the mistaken belief rather than on a reasonable or true belief and that, in those circumstances, the accused has never chosen to do an unlawful act; the unlawfulness of the act results from the mistake rather than the choice. It may be, of course, that making the mistake is itself offensive, and for this reason Parliament may introduce reasonableness requirements; the defence of self-defence in s. 34(2) has such a reasonableness requirement. However, it can certainly be argued that there is still a principled distinction between the accused who honestly believed the force was necessary and the accused who did not, and that the distinction can be recognized in the difference between murder and manslaughter.

There are, therefore, two recognized principles behind the test enunciated by the Alberta Court of Appeal, even though the Court itself did not articulate them clearly. Instead, the Alberta Court of Appeal focused on the lesser moral culpability of causing death when some force is justified but never explained the importance or relevance of the accused's belief that the force he or she used was necessary despite the fact that this was clearly an important part of their test. It should be pointed out that there are other possible tests and other possible principles for a qualified defence of excessive use of force in selfdefence. In particular, it is possible to devise a defence that is the equivalent of

the issue as there was in fact no intent as required for murder.

See supra note 3 , supra note 4 and supra note 5 .

$R$. v. Crothers (1978), 43 C.C.C. (2d) 27 (Sask. C.A.). Dickson, J. in Brisson, supra note 28, casts doubt on this decision by showing that the Court relies on a headnote from $R$. v. Stanley, supra note 32 , that includes a material error about the relevance of intent. While it is true that the Court does use the headnote, it appears to use it more as a short form for expressing the basic doctrine rather than as its main authority for that doctrine. The Court appears otherwise to be convinced of the value and availability of the qualified defence of excessive force.

R. v. Reilly (1982), 66 C.C.C. (2d) 146 (Ont. C.A.) adopting the obiter comments of Martin J.A., writing for the court, in $R$. v. Trecroce (1980), 55 C.C.C. (2d) 202 (Ont. C.A.) at 210-211. Pilon v. The Queen, [1966] 2 C.C.C. 53 (Que. C.A.). 
provocation in that it is based on the "ordinary" person responding out of instinct rather than the "reasonable" person responding out of rational assessment. The principle behind such a defence would be neither proportionality nor responsibility but compassion for the very difficult situations people may face and an understanding that reactions in such situations can be inappropriate.

Furthermore, in discussing the position in Australia, whence the concept appeared to have come, Dickson J. again took the most negative view. He quoted from two authors, Professors Howard ${ }^{37}$ and Elliott, ${ }^{38}$ whom he described as expressing "doubt" about or being "critical" of the doctrine. The quotations he used were indeed of the cold-water variety. However, in fact, neither author was opposed to a manslaughter verdict when the accused mistakenly used excessive force in self-defence; they were more concerned about the proper underlying principle or test for the doctrine. Professor Howard was of the view that it was unnecessary to develop any special defence for the principle that the Australian Courts were applying at the time. In his view, the proper result of the Australian analysis would be the characterization of the offence committed by the accused as a kind of criminal negligence giving rise to involuntary manslaughter and never murder. This was because the analysis was based on misjudgment of the circumstances. If it were desired to have the defence operate as a kind of voluntary manslaughter, its requirements would have to be changed to be the equivalent of provocation. ${ }^{39}$ In this case, there would be no requirement of misjudgment but simply a requirement that the victim had placed the accused in a position where he had a right to use violence, albeit not this much. Professor Elliott considered that the defence as it stood in Australian precedent was illogical and ineffective in its reliance on a situation where the accused was entitled to respond with violence to a serious attack and unknowingly overreacted. His view was that the current doctrine should be legislated away, but replaced by one that focused on whether the accused had behaved as an ordinary, not a reasonable, person might ${ }^{40}$ (noting that an ordinary person is capable of unreasonable and disproportionate retaliation). In other words, both authors had problems with the legal analysis on which the doctrine was based and the usefulness of the test that had developed; neither wished to scrap it entirely.

While Dickson J. was clearly justified in suggesting that the doctrine did not, as yet, have a solid foundation in principle, he was not required therefore to reject it absolutely. Across jurisdictions, there existed a substantial sentiment in favour of such an idea which deserved to be taken seriously. The fact that Canadian Courts of Appeal and the Australian High Court had not yet worked out a clear and consistent philosophy did not prevent the Supreme Court of Canada from kneading the test and the potential philosophies into a workable (even though by no means final) product. However, the lack of a clear and ready-made analytical framework appeared to be an impassable barrier.

37 C. Howard, "Two Problems in Excessive Defence" (1968) 84 L.Q.R. 343.

38 I.D. Elliott, "Excessive Self-Defence in Commonwealth Law: A Comment" (1973) 22 Int. and Comp. L.Q. 727.

$39 \quad$ Supra note 37 at $356-360$.

* Supra note 38 at 737-738. 
Perhaps one reason for this can be found in Dickson J.'s approach to the problem of codification. He pointed out that in the Code, the distinction between murder and manslaughter was based on whether or not an intent to kill, or to cause bodily harm knowing that it was likely to cause death, existed. There was a specific provision for provocation reducing murder to manslaughter and several specific provisions covering various aspects of defence of the person or property and allowing these as full defences. There was no mention of there being any defence, qualified or otherwise, when the force used went beyond what was reasonably necessary. The general provision that allowed common law defences to be used (s. 8(3)) was not meant to interfere with such a clear and all-inclusive statutory scheme.

There was nothing wrong in principle with this approach and I have argued elsewhere that it fits well with a view that Parliament is the proper source of policy decisions about when society will allow people to behave in ways that otherwise contravene the basic mental and physical requirements of our criminal law. ${ }^{41}$ The reasonableness requirement does appear to be central in ss. 34 and 35 , and no alternatives or exceptions were provided for. Moreover, as Dickson J. pointed out, the Commission whose Draft Code formed the basis of the Canadian Criminal Code of 1892 appeared to have considered the issue. ${ }^{42}$ Dickson J. summarized its conclusion in the following way: "In the view of the Commissioners, provocation and full self-defence, if I may use that term, exhausted the possibilities. ${ }^{143}$

It is worth noting, however, that he did his own analysis a great disservice in his later decision in Faid, where the Court adopted his conclusion and reasoning from Brisson. In Faid, Dickson J. raised a potential ambiguity in s. 34, the main self-defence section:

A final point: in explaining s. 34(2) to the jury the trial judge made the following observation:

"...even if the accused intended to cause death or grievous bodily harm, his actions may have been justified as self-defence under Section 34(2) of the Criminal Code."

Two interpretations of s. 34(2) are possible: (i) the one taken by the trial judge, namely, that s. 34(2) provides a justification against an intentional killing done in self-defence, and (ii) that s. 34(2) is not applicable in an intentional killing situation, and provides no defence to an intentional killing, because the purpose of the section is to justify force which would otherwise be unlawful, the force so justified being the force referred to in s. 34(1), namely, a force not intended to cause death or grievous bodily harm likely to cause death. It may be that the trial judge's interpretation is the correct one, when one reads s. 34(2) together with s. 37 of the Code. It is not necessary to decide the point in this case, however, because even if the trial judge's interpretation is erroneous, the error worked to Faid's 318-19.

2 U.K., H.C. "Report of the Criminal Code Bill Commission" No. 2345 in English Parliamentary Papers (1879), vol. 36, at 157.

$43 \quad$ Supra note 28 at 116. 
advantage, in so far as this interpretation of s. 34(2) made the defence therein provided available to Faid, which it would not be if the other interpretation is the correct one. ${ }^{44}$

Dickson J.'s alternative here would leave the accused who intentionally killed in selfdefence, in circumstances that made the killing both reasonable and necessary, without a defence. Because Dickson J. had already eliminated the possibility of using s. 8(3) to bring in the common law defence of self-defence (see above), and had already indicated that the difference between murder and manslaughter was intent, he would have no alternative but to convict such a person of murder. Whatever one's view of the qualified defence of excessive force, such a result would be untenable. Dickson J.'s conclusion that the defence of the person sections are an extensive and complete package is certainly not supported by his literal and unreasoned interpretation of one of those sections that would leave a huge unsupportable gap in the self-defence provisions. Indeed this is only one example of the confusing nature of the self-defence sections. They do not form a clear seamless pattern but require a lot of juggling when the courts are applying them. They could certainly be interpreted so as to allow the courts to fill in the necessary gaps and develop new solutions to problems that arise.

Dickson J.'s third argument was that the charge to the jury in such cases would be so complicated that a jury could not be expected to do its job properly. In Faid, he followed this concern with the related concern that the result would be compromise verdicts of manslaughter in cases where a complete acquittal or a conviction of murder would be a more appropriate result.

In the end, the approach the Supreme Court adopted to the well-intentioned accused who used what might be considered to be excessive force in self-defence allowed such an accused to argue only that (1) his or her actual belief that the force was necessary was a good indication that the belief was reasonable in these exigent circumstances and therefore full self-defence applied; (2) he or she did not intend to cause death or bodily harm given circumstances that did not allow time for thought; or (3) the circumstances were such that the qualified defence of provocation could apply (i.e. the victim's attack would have provoked an ordinary person into losing their self-control and the accused's response was a result of sudden loss of control). In the first case, the accused would be acquitted on the basis of self-defence; in the second and third, the accused would be convicted of manslaughter, not murder. However, if an actual intention to cause death was shown, if the reasonable person in these circumstances would not have thought killing necessary, and if the ordinary person in these circumstances would not have been provoked, the proper result was a murder conviction. 


\section{COMPARISON OF THE TWO APPROACHES TO EXCESSIVE FORCE}

\section{The Treatment of the Concept of Excessive Force}

What, then, was the difference between the Alberta Court of Appeal and the Supreme Court of Canada on the qualified defence of excessive force in self-defence? The Alberta Court of Appeal noticed a groundswell of opinion in the cases from Australia and British Columbia, understood the feeling that created it and joined it. They struggled with its rationale, its fit with the Canadian Criminal Code and its requirements, but they saw something positive in it in terms of human morality, and put that first. Throughout the opinions mentioned above, no matter how incomplete or tentative, the sense that this is the right thing to do comes through.

There is no such feeling in the Supreme Court of Canada judgments. There is no mention of moral culpability, or reduced moral culpability; there is discussion of intent as the legal test differentiating murder from manslaughter, and of statutory interpretation and of a lack of principle. The sense one gets is that the Supreme Court would only accept a perfectly-developed doctrine; they appeared to have no interest in thinking about the rightness of the result and whether their job was to assist in the formulation of the principle.

It may be that there was an underlying rationale for the Supreme Court's reluctance to deal with this concept. For one thing, it may be that the facts of the cases were not persuasive enough. Here, I am referring to the scenario where all of the cases in which the issue is raised are unsympathetic; where the Court, despite the abstract attractiveness of the doctrine, recognizes that it would, in fact, work only as a compromise or a disruptive influence in ugly and questionable cases. To be honest, the facts of all of the cases I have discussed may fit into that category, and it is possible that the Supreme Court looked at this pattern and saw that otherwise available arguments would work in the cases we would want them to work in and that it unnecessarily and wrongly muddied the waters to introduce this doctrine into cases that were already murky; in those cases, such doctrines would only work to relieve judges and jurors of their obligations to think hard about acceptable and unacceptable human behaviour. For instance, the Supreme Court's discussion of the danger of compromise verdicts may be related to this concern.

In addition, the argument has been made by others ${ }^{45}$ that the test adopted by the Alberta and Ontario Courts of Appeal, one that requires both a serious attack that the accused is entitled to respond to with violence and an honest belief that the amount of force used in response is necessary, is too stringent and would have more of the effect of denying accused full acquittals where they would otherwise be available than to provide those who would otherwise be convicted of murder with a lesser alternative when the circumstances reduce the culpability of the behaviour. The Supreme Court may well have been concerned that the introduction of the concept would have this detrimental effect. 
Both of these concerns about the doctrine are based on reasoning that fits well with a legal process that relies on experience and fairness and wisdom and works those concepts into principles. This reasoning would take the same approach as the Alberta Court of Appeal but look at the issue from a broader and more critical perspective. Unfortunately, that does not appear to be what the Supreme Court was doing. They certainly did not describe their approach that way, nor did they provide the material or the evidence necessary to support it. Instead it seemed to be more a case of not being convinced that the doctrine was right, based on difficulties others had had in justifying it, explaining it or fitting it into a codified system. Such a response must have seemed sterile to the Courts of Appeal who had struggled with the doctrine over many cases.

\section{The Treatment of the Criminal Code}

The explanation that lies at the heart of the Supreme Court's approach here appears to be the existence of the Code. The first question is whether the Court should look beyond the Code to find issues and solutions. In other words, to what extent is common law still available? The Supreme Court here appeared to be looking for two things - some indication in the Code that there was room for this new principle and a strong common law analysis that might override any resistance the statutory framework might provide. In this case it found neither. The Court found no historical common law analysis that allowed the defence, a current analysis that was fragmented, weak and subject to strong criticism and a concept that was unworkable in the criminal justice system. With regard to the statute, the Court found that the Code created a clear distinction between murder and manslaughter based on intent, with specific defences of provocation and self-defence that overrode the general analysis. The history of the Code made it clear that this issue had been addressed and rejected in the past. While this did not preclude the Court from revisiting the subject, in light of this statutory framework and history, the common law would have to be compelling, and it was not.

In essence, this legal analysis meant that the Court never actually dealt with the policy and principle of the proposed defence. Because of the statutory framework, it did not approach the subject as an open issue; the first question was in fact whether the issue was open. However, to resolve this, it did not look only at the statutory scheme, but also at the strength of the doctrine proposed. Since neither beckoned persuasively, the Court left the door closed.

The approach is in fact a sensitive one - sensitive to the fact we do have a Code but also sensitive to the fact that the Code is not necessarily the final word in such a complex area. There may be more of a problem with the actual use made of the approach here. As pointed out above, the Supreme Court of Canada used a preliminary round to determine if there was enough of an issue for it to enter into a discussion of the concept itself. On the common law side, what it was looking for was a well-established and justified test. That was the wrong thing to be looking for, because that is not the way the common law works. In fact, there were strong indications, under the common law approach, of a real issue. Those indications were the continual sense of a need for this defence in the lower courts, its adoption by Courts of Appeal in Alberta and elsewhere, and the discussion of the defence in terms of "a reduced moral culpability." These features indicated that there 
was a problem that needed discussion. If the common law is to have any impact on the Code, it still has to be allowed to work itself out as the common law does, and the Supreme Court itself is part of that process. In other words, in the face of these indicators of a provocative common law issue, the Supreme Court must not renege on its responsibility to do a close examination of the potential of the issue.

On the statutory side, the Supreme Court stopped when it ran into the twin peaks of a clear expression of intent by the English Commissioners whose Draft Bill founded the Canadian Code, and a seemingly inhospitable statutory framework. Again, the Court stopped too soon. The English position in both 1892 and 1982 on this subject was very clear; however, the issue here was the Canadian approach in 1982, and this was not subjected to deep analysis. Any true review of the Code provisions would reveal that despite appearances of glossy impenetrable coverage, the concepts of self-defence, preventing crimes, excessive force and provocation are full of cracks that need constant filling by the courts. The issue here, then, was whether this was one such cranny. This required more than a mere glance at the surface of the Code; it required a more in-depth analysis of its operation. In particular, it required some new analysis of $s .26$, the section dealing with excessive force, and its relationship with s. 34(2), plus some consideration of the difference between justification and compassionate mitigation. Specifically, the Court should have considered the fact that the codified structure of murder removes the possibility of compassionate mitigation through sentencing (murder being one of the few offences with a mandatory sentence of life imprisonment). Such consideration might have made the Court more aware of the extra need for restraint in closing off other avenues of mitigation.

The Alberta Court of Appeal appeared to be much more in tune with the felt need for this defence and thus responded more positively to the idea. It also began to work on the principled basis by discussing the situations in other jurisdictions. However, the level of its analysis was not high enough to come to terms with some of the real difficulties inherent in defining and applying the defence and, therefore, it too failed to do a persuasive common law analysis. Moreover, its work with the Code was weak. In fact, it might almost be said that it did not recognize the Code as a significant factor in the analysis. The result was that its argument failed to persuade the Supreme Court of Canada.

Each Court showed strength at one part of the process of mixing common law and Code, but neither Court provided a full analysis showing the proper balance between them.

\section{THE RELEVANCE OF VICTIM'S CONSENT IN ASSAULT CAUSING BODILY HARM}

\section{A. INTRODUCTION}

The Supreme Court of Canada does not always take such a sterile approach to interpreting the Code. Indeed, in regard to the next issue to be discussed, the Supreme Court has shown a willingness to ignore the strict and clear language of the Code and to 
focus on the common law and its reflection of right and wrong. Here, the issue is whether the consent of the victim operates as a defence in charges of assault causing bodily harm (s. 267) or aggravated assault (i.e. an assault which wounds, maims, disfigures or endangers life (s. 268)). The problem arises because the definition of assault in s. 265 of the Code includes a requirement that the force be applied without the consent of the victim (i.e. consensual application of force is not assault) and that definition is made applicable to all offenses involving assault. However, this interpretation does not accord well with current perceptions of what is right and wrong and what criminal law should be about.

s.265(1) A person commits an assault when

(a) without the consent of another person, he applies force intentionally to that other person, directly or indirectly;

(b) he attempts or threatens, by an act or a gesture, to apply force to another person, if he has, or causes that other person to believe on reasonable grounds that he has, present ability to effect his purpose; or

(c) while openly wearing or carrying a weapon or an imitation thereof, he accosts or impedes another person or begs.

(2) This section applies to all forms of assault, including sexual assault, sexual assault with a weapon, threats to a third party or causing bodily harm and aggravated sexual assault.

(3) For the purposes of this section, no consent is obtained where the complainant submits or does not resist by reason of

(a) the application of force to the complainant or to a person other than the complainant;

(b) threats or fear of the application of force to the complainant or to a person other than the complainant;

(c) fraud; or

(d) the exercise of authority.

(4) Where an accused alleges that he believed that the complainant consented to the conduct that is the subject-matter of the charge, a judge, if satisfied that there is sufficient evidence and that, if believed by the jury, the evidence would constitute a defence, shall instruct the jury, when reviewing all the evidence relating to the determination of the honesty of the accused's belief, to consider the presence or absence of reasonable grounds for that belief.

\section{B. ALBERTA COURT OF APPEAL}

The Alberta Court of Appeal has recently dealt with this issue in three cases $-R$. v. Carriere, ${ }^{46} R$. v. Bergner ${ }^{47}$ and $R$. v. Loonskin. ${ }^{48}$ In all three cases, the accused and the victim were involved in what the trial judge identified as a consensual fight (although, as we shall see, in two of the cases the Court cast serious doubt upon that characterization) and the accused seriously harmed the victim. In Carriere, both 
participants in the fight had knives and the accused stabbed the victim in the abdomen. In Bergner, the accused punched the victim in the head repeatedly, pushed his head back into a wall and then, when the victim collapsed, kicked him in the face and ribs, ultimately causing serious face and head injuries that resulted in blindness in one eye. In Loonskin, the accused hit the victim many times and then bit off his ear.

\section{1. $R$. v. Carriere and $R$. v. Bergner}

The Court of Appeal's approach to the first two cases was similar. It reviewed the cases in both Canada and Britain that had dealt with the issue of whether a person can consent, for criminal law purposes, to have bodily harm done to them outside of sport or medical treatment. While it appeared that in England there was a fairly uniform policy that a person's consent to bodily harm should not be a defence when no societal purpose was achieved, in Canada the results had been more varied. The difference between the two jurisdictions is largely due to the apparent requirement in the Code of "lack of consent" as an element in any assault. The Court of Appeal had no trouble determining that the effects of consent had to be limited. Without discussion or analysis, it accepted the view that the provision must be interpreted in light of the common law and be found to incorporate the limits of the common law. ${ }^{49}$

Where the Court of Appeal did provide much more food for thought in these cases, however, was in the exercise of determining what the limits of the common law were. In considering this question, the Court of Appeal was not concerned with the limits that had been established elsewhere but was more interested in examining the reality of so-called consensual fights and the problems of trying to control them through the criminal law. For instance, in Carriere, the Court questioned the approach of the English Court of Appeal in the Attorney General's Reference (No. 6 of 1980) ${ }^{50}$ and particularly whether it resolved the difficulties created by the so-called "manly sports". In the A-G's Reference, the English Court of Appeal had focused on the intent to injure and the social value of the exercise in which the accused and victim were engaged, in determining whether consent would provide a defence to an assault. Their basic policy was that people should not try to harm each other "for no good reason." They held that if there was any intent to injure or any actual injury, consent was not a defence unless the conduct took place as part of an activity that was accepted in the public interest, for example, sports and games, lawful chastisement, medical treatment or dangerous exhibitions.

The Alberta Court of Appeal directed its attention, albeit briefly, to the workability of this test. It pointed out that even in the so-called "sports" there may be a clear intent to injure and that it is questionable whether the mere fact that the force happens within a sport justifies it as "for a good reason." They questioned, for instance, whether a fight is justified just because a school teacher forces the combatants to put on boxing gloves and fight it out in the gym rather than on the playground. Furthermore, given the wide ambit 
of the Criminal Code definition of "bodily harm", ${ }^{51}$ neither intent to cause bodily harm nor the causing of bodily harm provides much of a barrier. The concern of the Court appears to be whether this test is strong enough or consistent enough with rational distinction to override the apparent requirement of lack of consent in the assault provisions of the Code.

The Court in Carriere proceeded to confirm this concern in its actual decision. It found that, when weapons are involved, public policy nullifies consent; therefore both combatants in Carriere committed assault. It explicitly refused to deal with the situation where no weapons were involved but instead provided a clear indication that, to avoid the difficulties inherent in these policy decisions, the courts should first ensure the reality of the consent. As Laycraft C.J.A. stated for the Court: "I observe in passing, however, that the 'consent' in many of these 'fair fights' is often more apparent than real. ${ }^{152}$ This seems a wise injunction and one, as we shall see, that is often ignored.

Bergner raised just such an issue. Bergner challenged the victim to a fight by hitting him on the back of the head and indicating that they should go outside. The victim, who was very drunk, complied, but the fight was totally one-sided in Bergner's favour; Bergner was even able to fight off a bystander who attempted to intervene. Bergner also kicked the victim several times in the face and ribs with his leather boots while the victim, apparently unconscious, was lying on the ground. The judge found that the kicking was not consensual but that the injuries could not be attributed beyond a reasonable doubt to the kicking. Therefore the accused was convicted of assault only.

The Court of Appeal referred back to the review of the cases it had performed in Carriere. Once again, it pointed out the difficulty of administering the test from the $A-G$ 's Reference. "The friendly fight is a rare phenomenon," the Court said, when mentioning that even in hockey or football there is a certain amount of choler behind the fights ${ }^{53}$ (and even, I would argue, behind more integral parts of the play).

Moreover, the Court drew an important distinction between breach of the peace considerations (which it found to be handled through the summary conviction offence of causing a disturbance by fighting (s. 171)), and danger or harm considerations. It indicated that, to the extent that the English policy rested on breach of the peace concerns, the approach in Canada might differ from that of England, since in Canada the assault provisions are not directed at breach of the peace and therefore the elements should not be applied so as to solve breach of the peace concerns. In fact, however, the English policy analysis in the $A-G$ 's Reference specifically eschewed a breach of the peace slant when it rejected a public/private distinction in favour of a distinction based on intent to cause or causation of injury. means any hurt or injury to the complainant that interferes with the health or comfort of the complainant and that is more than merely transient or trifling in nature." 
Ultimately, because it found any distinctions based on anger or intention to cause injury impossible to administer, the Alberta Court of Appeal refused to limit the role of consent in assault except in those cases where weapons were involved and, therefore, a clear line could be drawn. However, it did strive to limit the applicability of the consent defence in other cases by indicating that the consent would have to be true consent; the Court stated that where the victim is drunk or in a poor position to exercise independent judgment, "[t]o speak of 'consent' or 'a fair fight' ... does not relate to the real world." ${ }^{54}$ The Court then indicated that criminal negligence may be the proper charge in some of these cases (it seems probable that they suggested criminal negligence to avoid an argument that the accused had a mistaken belief in real consent if the consent itself were found to be invalid.) Ultimately, the Court of Appeal made it quite clear that they would not have found consent at all in this case but that they were constrained by the finding of the trial judge that the victim consented to the first part of this fight and therefore they dismissed the appeal.

\section{R. v. Loonskin}

Finally, the Court of Appeal dealt with the case of Loonskin..$^{55}$ In that case, the accused and the victim, who was intoxicated, bumped into each other. The victim apparently was fearful that the accused would attack him and, knowing his own vulnerability when he was under the influence of alcohol, decided to prevent it by grabbing the accused and forcing him against the wall. Unfortunately for him, that prevented nothing and the accused punched and kicked him and then bit off his ear. The trial judge found that the victim had consented but that consent to biting was not a defence since teeth were a weapon. The Court of Appeal raised the issue as to whether there was true consent, pointing out that even anticipatory self-defence is not the same as consent. However, it held that it had to follow the finding of fact of the trial judge and that there was therefore consent. On the other hand, without dealing with the question of whether teeth are a weapon, it held that the consent given did not extend to being bitten and that therefore the conviction on the aggravated assault charge was upheld.

\section{Critique}

Throughout these cases, the Alberta Court of Appeal demonstrated a sensitivity to the realities of everyday life and the realities of applying legal rules to situations of everyday life. It preferred an approach in which, except where weapons are involved, the presence of true consent is the line of distinction between criminal activity and non-criminal activity. However, it tempered this by looking very carefully at the nature of consent and requiring real consent. For instance, where the victim feels there is no choice, there is no consent, but where the victim actively and consciously chooses to fight as a true option, there is consent, and no assault, even if the parties then injure each other. 
It appears that the Court chose this approach for reasons other than pure policy. While it recognized that allowing participants to choose any form of "duking it out" would go too far and that it was possible to limit the requirement of lack of consent in the Code by interpreting it in accordance with the common law, it clearly felt unable to prescribe a test that could be applied in an even-handed manner. The only distinction it truly felt comfortable with was that between weapons and non-weapons. It felt that the $A-G$ Reference went too far in that the reasoning in that case did not recognize the potential combinations that could arise in sporting and fighting situations, and to differentiate their criminality on the basis of untested distinctions worried them. Therefore, the Alberta Court of Appeal chose to err on the side of excluding behaviours from the criminal law; at the same time, it demanded that the element of consent be applied consistently with the policy behind allowing consensual physical attacks in the first place, i.e. the consent had to be real.

This strong consent requirement is consistent with what is happening in sexual assault ${ }^{56}$ and in Charter analysis. ${ }^{57}$ In effect, it introduces a method by which a court may control behaviour without reducing freedom. It recognizes consent as relevant but only when it embodies true personal choice. The focus on the reality of consent as the issue is intended to gradually educate society to the very real control bullying behaviour exerts. If the courts no longer assume that participation means consent and start to question the methods by which people are persuaded to resolve disputes by violence, gradually society's (and individual's) acceptance of violence as a form of dispute resolution will diminish. In other words, the Court of Appeal's approach would ultimately result in changing what is acceptable by changing our perception of what is actually happening.

\section{THE SUPREME COURT OF CANADA}

\section{R. v. Jobidon}

The Supreme Court of Canada's approach to the same issue was quite different. In $R$. v. Jobidon, ${ }^{58}$ the Court was faced with a manslaughter charge arising out of a fight which the victim started in a bar (where the victim had the upper hand) and which continued in the parking lot. Here the accused waited for the victim and, after an exchange of words, got in the first blow, one of great force. He followed up with a flurry of punches; the victim was knocked unconscious by the first blow, never fought back and died shortly afterwards. This was clearly a consensual fight, at least as far as the first and most damaging blow was concerned - if anything, the victim was the aggressor -

For example, in recent amendments to the Criminal Code (S.C. 1992, c. 38), Parliament has introduced additional requirements for a finding of consent in sexual assault cases, including that the consent must be given by the complainant themself and that the complainant's capacity to consent must not have been impaired by alcohol or other condition.

57 For example, an accused's waiver of the right to counsel has been found to be ineffective where the accused was drunk (Clarkson v. The Queen (1986), 25 C.C.C. (3d) 207 (S.C.C.)), and where the accused did not understand that legal aid was available (R. v. Brydges (1990), 53 C.C.C. (3d) 330 (S.C.C.)).

ss (1991), 66 C.C.C. (3d) 454 (S.C.C.) [hereinafter Jobidon]. 
therefore it did not raise exactly the same kinds of issues as in the Alberta cases. However, it is clear that, because it was a fist fight, the Alberta Court of Appeal would have found consent to be a relevant consideration in the case despite the serious consequences. The Supreme Court disagreed.

The Supreme Court did a very full analysis of the process by which one can legitimately incorporate restrictions on the relevance of consent into an offence defined in a way that includes lack of consent. Its main position was consistent with that which appeared most to influence the Alberta Court of Appeal - that the lack of consent requirement had been restricted at common law, that the Code simply enacted the common law and that therefore the Code requirement contained similar restrictions. However, the Supreme Court clearly considered this a much more serious issue than did the Alberta Court of Appeal and spent the time necessary to do a nice analysis of the question. It dealt with Parliamentary intention as a real concern and its analysis included these points:

1. there have always been these types of policy-based limitations on consent (for instance, without limitations, it would be an assault to dress a child who did not want to be dressed);

2. there was no indication that Parliament intended to eliminate the common law or these limitations (for instance, the specific vitiating factors in s. 265(3) also just help to spell out the common law; they do not replace it); and

3. there is a reason that some common law limits are legislated (as in s. 265(3)) and these are not, and it has to do with the difficulty of expressing these limitations precisely in a way suitable to legislation.

The Court also recognized that the common law limitations should be current ones, and not the ones that might have existed when the legislation was originally passed. Therefore, they reviewed recent cases (which were not consistent enough to be of much help) and current policy. In the current policy analysis, their major point was that autonomy is not the only value that the criminal law protects: "...it is most unseemly from a moral point of view that the law would countenance, much less provide a backhanded sanction to the sort of interaction displayed by the facts of this appeal." ${ }^{159}$

Finally, the Supreme Court dealt with the actual test to be applied. They noted that they were only dealing with fist fights between two adults in the case before them and, for the purposes of that type of case, established that "consent between adults intentionally to apply force causing serious hurt or non-trivial bodily harm to each other in the course of a fist fight or brawl" should be vitiated. ${ }^{60}$ The Court admitted that there would have to be further case-by-case development of the test and that there might well be further limitations on consent. Their view was that this still allowed rough sporting events (as 
long as the activities were within the customary rules of the game), medical treatment, and stunts (?!), because of their significant social value. They also indicated that consent would still be relevant in the case of minor injuries or "'ordinary' schoolyard scuffles" because "[t]he bodily harm contemplated by the test is essentially equivalent to that contemplated by the definition found in s. 267(2) of the Code, dealing with the offence of assault causing bodily harm. ${ }^{\text {"161 }}$ Of course, this definition still encompasses a large number of fairly minor harms; it will not only be in cases of maiming or death that consent will now be irrelevant. It is by no means clear that, in actual application of the test, consent will be a factor in schoolyard scuffles (a black eye or bloody nose can be bodily harm).

Moreover, the Supreme Court failed to come to terms with the difference between intentionally applying force and intentionally causing harm. There are some indications that the test is only to apply where the accused intended harm, and harm actually resulted ${ }^{62}$ but the test ultimately enunciated does not make this clear. Moreover, in discussing the application of the test, Gonthier J. later referred to $R$. v. Barron ${ }^{63}$ as an example of the type of case where consent by non-adults might not be a defence because there was an intent to cause harm and harm was caused. However, in Barron, there was an express finding that there had been no intention to cause bodily harm. Therefore, this aspect of the test is confusing.

\section{COMPARISON OF THE TWO APPROACHES TO CONSENT IN ASSAULT CAUSING BODILY HARM}

\section{The Treatment of the Concept of Consent to Assault Causing Bodily Harm}

It should be noted that the Supreme Court did not even attempt to resolve some of the difficulties raised by the Alberta Court of Appeal, and yet its test is already difficult to apply. Its response might well be that that is the reason for case-by-case development. The Alberta Court of Appeal would seem to be more concerned with the lack of predictability that would then invade the criminal law and the potential for inconsistency that would arise therefrom. Underlying the difference of opinion, however, may also be a different view of the role of criminal law and its place in society. The Supreme Court of Canada has developed the view that violence is an unacceptable way to resolve disputes and sees

Ibid. at 495.

62 For example, ibid. at 490, Gonthier J. states:

Attorney General's Reference makes it clear that a conviction of assault will not be barred if 'bodily harm is intended and/or caused'. Since this test is framed in the alternative, consent could be nullified even in situations where the assailant did not intend to cause the injured person bodily harm but did so inadvertently. In Canada, however, this very broad formulation cannot strictly apply, since the definition of assault in s. 265 is explicitly restricted to intentional application of force. Any test in our law which incorporated the English perspective would of necessity have to confine itself to bodily harm intended and caused.

However, note that the section only requires that the force be intentional, not that the bodily harm be intentional. 
the criminal law as an important means by which to communicate that ideal and educate society. The Alberta Court of Appeal may well see the criminal law as more reflective of current values, attempting to make small moves forward by requiring an accurate assessment of people's motivations, but not imposing major shifts on society. One might even say the Supreme Court is the court of theory while the Alberta Court of Appeal is more concerned with practical reality.

\section{The Treatment of the Criminal Code}

Finally, there is the issue of Code interpretation. The Alberta Court of Appeal was willing to allow common law accretions to our criminal law in both the excessive force in self-defence cases discussed earlier and in the consent to bodily harm cases. The Supreme Court of Canada refused to bring common law developments into self-defence interpretation in the early 1980s but did allow them in consent to bodily harm cases in the early 1990s. One of the reasons for the different results in the Supreme Court may well be the time difference itself. In the years intervening between Brisson and Jobidon, the Supreme Court had handled many Charter cases and had learned to deal with developments in theory; this may have made it feel more comfortable in handling the arguments for new developments presented in Jobidon. Another reason may be that it felt the actual development being requested in Jobidon was more cogent than that in Brisson (although, as indicated above, it may have been more confusing than the Supreme Court appreciated.)

However, the simplest explanation for the difference in the Supreme Court's approach in the two cases is that the Supreme Court is more willing to acknowledge previouslyexisting common law as part of the Code than new developments. In fact, it is possible to extract a principle from this comparison that the question of whether the door is open to look at common law modifications to the Code is based on whether any common law accretions existed at the time the Code was passed; once the possibility of common law variations is accepted, the ones to incorporate are those that exist now. In other words, the fact that the Code was not absolute was established at the time of enactment but the nature of its lack of absoluteness would change over time.

While the Supreme Court's approach may be easier to justify under current statutory interpretation principles than the wholesale introduction of common law developments, it is a poor principle on which to base the interpretation of a Code. If the common law fine-tuning existed at the time the Code was passed and was intended to be part of the interpretation of the Code, the only reason not to specifically include it in the legislation itself was that it was difficult to legislate. Examples of the factors that make something difficult to legislate are that the concept is so integral that it is not easily identified as a problem or that it is not easily articulated. However, there is nothing about these kinds of reasons that would indicate that the legislation is more open to future developments in this area than in other areas. These reasons may help the Courts interpret the past; they do not tell us much about the present. 


\section{CONCLUSION}

Instead of basing the openness of the Code to development on fortuities of history, the Courts need to appreciate the special nature of a Code, which is a general, long-term, integrative piece of legislation. Thus, it could reasonably be assumed that such legislation is intended to be as responsive as possible to the changing needs of society, in the absence of reasons for being constant and immutable. The main reasons for resisting change would be a need for certainty or, perhaps, even-handedness. These reasons apply well to the legislating of offences themselves; there is a felt need for certainty and even-handedness in the actual definition of unlawful behaviour. This is reflected in the Code itself in s. 9 which eliminates common law offences and offences not specifically set down in Canadian legislation or regulation. However, these reasons do not apply to other aspects of substantive criminal law, a perspective that is reflected in s. 8(3) and its allowance of common law justifications and defences.

Thus, the Courts are entitled to be more open with the Code than they might be with other pieces of legislation. They do not have to rely on vagaries of the past and, indeed, should not, as such reliance would lead to a very inconsistent use of the common law. Rather, the Courts can apply the approach argued for earlier in this paper. They can look to the Code to see if there is room for the principle being discussed (without being too ready to read the Code in a restrictive way) and also do a thorough common law analysis of the principle to see if it will stand as a principle and overcome whatever statutory resistance exists. If this job is done properly, the Code can play a strong but not stultifying role in Canadian criminal law.

However, for this process to work, it is essential that the common law analysis be thoughtful, fair and careful, with attention paid to the difficulties of principle and application inherent in any common law development. It has been the position of this paper that, at least in the context of the two topics discussed, the Alberta Court of Appeal has demonstrated an understanding of the responsive nature of the common law and a facility in dealing with the practical application of criminal law that the Supreme Court has lacked. A truly effective method of common law development within Code analysis would require a blending of the skills demonstrated by both Courts. 